\title{
The Ramadan Sonnets
}

\author{
By Daniel Moore. West Bethesda: A Jusoor Book-Kitab and San \\ Francisco: City Lights, 125 pp.
}

Best book of poems I've read in years by a contemporary and have had the pleasure of being lifted by, shot into the orbit of harmonious rapture grins and the joyousness of countless YES, O, YES. The collection resonates and purifies the deep sweet water in the cells where the real self drinks. The resonating builds stanza by stanza, poem after poem, informed by an American spiritual and mystical lineage from Transcendentalism to the Beats of the Beatitude Vision into as-yet-to-be identified and named Third Wave, holding in its unnumbered beckoning hands the world's mystical poetry body. Moore's spectacular contribution to this present building surge arrives before his audience with a thorough immersion in Islam's Sufi way. This is experience inspired into song, not a complex geometry of imaginary gymnastics afloat in an alienated mental life.

His outbound living as an example wedded to the deep dive that makes for an inner expansion wider than any exterior stepping out can accomplish is, to a nonpractitioner, an unfathomable paradox. This inward-most plunge drops the body's limited physical senses and mind and allows for a direct knowing rarely found in today's American poetry. While moving through and using as subject temporal moments, actions, and things, the eternal and the divine shine through the transitory. At times he evokes this light to such an extent the daily occurrence becomes but a shadow play.

More striking, all of these poems were written during one month, that of Ramadan, while living in Santa Barbara prior to the author's move to Philadelphia to live in the light of a denser Muslim experience than what was available. The poems range from the well-known, long Beat-like free verse line, a line that he has raised to a level eclipsing the older Second Wave, to the formal sonnet with surprising rhymes and meaning behind the meaning so that the form, unlike most contemporary attempts, is secondary. While autobiographical Ramadan experiential poems, these are also-and significantlyboth outer and inner foods that can nourish one to push forward into a more perfect reflection of human potential. Among mystics, the saint is the normal human condition; anything less is wanting.

Important as well, or maybe more important, the poems move the nonpoetry audience, because they are readily accessible from the details of everyday stuff to transcending, straight-foward Sufi narrative-they are not occulted by esoteric poetic posturing of the common bob and weave and obscure reference or gesture. His inward reaching has created an outward stretch far beyond the usual and sad condition of today's American poetry.

Karl Kempton Visual Poet and Book Reviewer Oceano, California 